Article

\title{
Adventure Tourism in the Spanish Population: Sociodemographic Analysis to Improve Sustainability
}

\author{
Jorge Rojo-Ramos ${ }^{1}{ }^{\oplus}$, Rubén Vidal-Espinoza ${ }^{2}$, Roxana Paola Palacios-Cartagena ${ }^{1}$, Carmen Galán-Arroyo ${ }^{1}$, \\ Fernando Manzano-Redondo ${ }^{1, *(\mathbb{D})}$, Rossana Gómez-Campos ${ }^{3}$ and José Carmelo Adsuar ${ }^{1}$ (D) \\ 1 Department of Health, Economy, Motricity and Education (HEME) Research Group, \\ University of Extremadura, Avda. de la Universidad s/n, 10003 Caceres, Spain; jorgerr@unex.es (J.R.-R.); \\ ropalacio@alumnos.unex.es (R.P.P.-C.); magaar04@alumnos.unex.es (C.G.-A.); jadssal@unex.es (J.C.A.) \\ 2 Facultad de Educación, Universidad Católica Silva Henriquez, Santiago 8330225, Chile; rvidal@hotmail.com \\ 3 Departamento de Diversidad e Inclusividad Educativa, Universidad Católica del Maule, Talca 3466706, Chile; \\ rgomez@ucm.cl \\ * Correspondence: fmanzanoa@alumnos.unex.es
}

Citation: Rojo-Ramos, J.;

Vidal-Espinoza, R.;

Palacios-Cartagena, R.P.;

Galán-Arroyo, C.; Manzano-Redondo,

F.; Gómez-Campos, R.; Adsuar, J.C.

Adventure Tourism in the Spanish

Population: Sociodemographic

Analysis to Improve Sustainability.

Sustainability 2021, 13, 1706. https://

doi.org/10.3390/su13041706

Academic Editors: Jesús

Manuel López-Bonilla and Luis

Miguel López-Bonilla

Received: 29 December 2020

Accepted: 21 January 2021

Published: 5 February 2021

Publisher's Note: MDPI stays neutral with regard to jurisdictional claims in published maps and institutional affiliations.

Copyright: (c) 2021 by the authors. Licensee MDPI, Basel, Switzerland. This article is an open access article distributed under the terms and conditions of the Creative Commons Attribution (CC BY) license (https:/ / creativecommons.org/licenses/by/ $4.0 /)$.

\begin{abstract}
In recent decades, tourism is an activity in continuous growth and generates a significant impact in the social, economic, and environmental fields. Adventure tourism mainly takes place in natural settings, where tourist immersion will generate, in addition to profits, an impact on nature and the conservation of natural areas. The purpose of this work is to analyze the sociodemographic characteristics of tourists who choose to carry out adventure activities, as well as the means of transport used. For this, we have carried out this study through analysis of the 2019 data file of tourists from the National Statistics Institute with a sample of adventure tourists of 380 people. The results of the analysis show that the type of tourist who does adventure sports is single people with a higher educational level and a stable professional situation. The most frequently used means of transport to a destination is private transport, and lodging accounts for the majority of accommodation. It should be noted that significant gender differences were found in the level of studies, professional status in the job performed, and type of accommodation. Finally, the profile of the adventure tourist will be very useful for planning sustainable tourism.
\end{abstract}

Keywords: adventure tourism; sustainable tourism; social responsibility; development

\section{Introduction}

Today, the tourism sector is one of the largest industries in the world [1]. Globalization is growing and undeniable and, in recent decades, has become an activity that is continuously growing in a very remarkable way in the economic, social, and environmental fields. The objective is not only for tourism to generate worldwide development, promoting employment in each destination but also for it to be sustainable over time, as shown in their study in Agüera [2]. In Spain, tourism is a fundamental pillar of the economy, being one of the main engines of growth and recovery. It is the second most visited country in the world, enjoying great tourism popularity worldwide [3].

Tourism is a social and cultural phenomenon [4] that is continuously growing, becoming an important foundation in the economy, society, and environment. It is one of the most diversified, personalized, and specialized industries [5], since it is classified by the purpose of leisure. Its main purpose is to improve the socio-economic development of the towns through their cultural, heritage, and natural potential, as well as to improve the conservation of natural, cultural, and heritage resources.

In studies such as that of Morillo-Moreno [6], it is even predicted that, in the future, tourism will be the most important economic activity on the planet, even surpassing oil.

The theory of tourism and the sociology of tourism or leisure shows how more and more account is taken of sports fans, which form part of the sociological research that is 
dedicated to grand sporting events [7]. Thus, authors such as Renata Wloch [8], underlines the fact that a majority of the studies on tourism and the use of free time analyzes the effect of mass sports events on the attractiveness of a particular destination from the perspective of tourism.

Taking the different types of tourism into account, active tourism is a good alternative for those tourists who want to experience new sensations. Active tourism is an activity that takes place within natural areas and is directly related to rural tourism, as pointed out by Roberts [9]. It offers a variety of activities that can be done in the middle of nature, whether in the water, air, land, snow, or ice.

Some authors [10] have defined active tourism as a trip or excursion with the specific purpose of participating in activities to explore a new experience, usually involving the perceived risk or controlled danger associated with personal challenges, in a natural environment or an exotic outdoor setting.

Having mentioned the term natural environment, it should be noted that another type of tourism will be sustainable or sustainability-related tourism. The Brundtland Report [11] defines sustainability as the capacity to cover the needs of current communities' equitably without compromising future localities (economic, social, and environmental). The aim is to achieve activities that generate wealth for the current location in such a way that it lasts over time.

With this in mind, Sancho and Buhalis [12] explain that sustainability is related to three fundamental events, which are quality, continuity, and balance, and, in this way, try to obtain a better quality of life for the community, conserving the importance of the environment, promoting unforgettable experiences for the tourist and obtaining productive profits for the locality [13]. At the same time, it tries not to produce negative impacts on the ecosystem.

In this way, according to Delgado [14], sustainable tourism refers to a form of tourism that meets the current needs of tourists, the tourism industry, and local communities, while trying to minimize the damage to the environment and, in turn, increase economic benefits. Likewise, regarding this, this study focuses on adventure tourism, another type of tourism that is generally undertaken in natural areas to have a positive impact on the conservation of natural and cultural resources [15]. This type of tourism is considered by Cruz-Blasco [15] as an opportunity to connect economic profitability, environmental conservation, and sociocultural respect. Likewise, the Adventure Travel Trade Association [16] is in charge of evaluating the potential of adventure tourism in the different countries of the world to carry out a strategy for the development of adventure tourism and to potentiate it.

As the main theme of the study, it is considered important to show the theoretical background on which adventure tourism is based. Some authors, such as Rantala et al. [17], conceptualize adventure tourism as a category, requiring a reconceptualization of the term in tourism research. In this line, the review of Cheng et al. [18] helps to map the current literature on adventure tourism and sets the goal of developing a stronger framework and a holistic understanding of this issue. It is suggested that adventure tourism should not be limited or be an analytical concept, as Sand and Gross [19] claim. Researchers must join forces to advance adventure tourism research, achieving applied research, and a direct link to management implications [19].

Within this theoretical framework, identifying the profile of the adventure tourist will become increasingly important to help adventure tourism companies. For example, studies such as that by Lötter et al. [20] try to identify the profile of this type of tourist in Pretoria; the study by Mohamed et al. [21] determined the profile and characteristics of visitors to Kampar from an adventure tourism perspective to plan the best approach for the promotion and marketing of adventure tourism; Giddy's study [22] in South Africa found that most of the proven characteristics and profiles of the adventure tourist have changed and need to be considered in marketing and management strategies and future development.

To achieve these purposes, a growing concern of tourist destinations is how to foster more sustainable forms of tourist mobility and make correct use of the means of trans- 
port [23]. There is no doubt that transport services are indispensable for the development of the tourism sector and that by strengthening and providing more sustainable mobility patterns, it is possible to reduce the environmental impact generated [23].

It is important to note the close relationship that this type of tourism has with sustainable development goals [24]. These objectives allow each country to work according to its realities, competencies, and level of development, obeying its national policies and priorities. It is an opportunity to root out poverty, fighting inequality and climate change, and its main objective is to build a different world for the next generation [24].

Focusing on adventure tourism, this is going to be the modality of the tourism that is carried out. taking advantage of the resources that nature offers and, generally, in unusual places, such as the sea, rivers or mountains. It is related to physical activity, including extreme sports or those that can offer new experiences or sensations [25]. Adventure tourism has now gained prominence, becoming one of the fastest growing segments of the market. It offers new experiences, integration with nature and greater sensitivity to the environment, and is becoming an attractive sector. In the study by Gil [26], reference is made to the goods and services offered, increasing the interest in these type of recreational and tourist activities in nature. Tourism is becoming one of the main sources of wealth worldwide, while sport is becoming consolidated as the main physical-recreational leisure activity [27].

Recently, however, there has been a worrying increase in the use of the natural environment for activities. These cause serious environmental impacts, such as the loss of biodiversity, the generation of waste, a drop in atmospheric quality, and water pollution, which have been previously affected by other types of action (infrastructure-motorways, reservoirs, forest fires, etc.). To achieve the maximum reduction in and control of these types of environmental impacts, they have raised awareness of the need to contribute to the overall process of sustainability in local development, and consequently, the paradigm of responsibility and sustainability in tourist destinations prevails. Thereby, it is interesting to know the profile of the tourist and the impact on the environment.

The adventure tourist is identified by an active, adventurous spirit, knowledgeable about environmental issues, who enjoys and admires direct contact with nature and seeks experiences that can enhance their knowledge [28]. In this way, these tourists conserve and use the maximum care for the environment in a sustainable way, trying to minimize the impact on the ecosystem.

The study by Vera-Rebollo and Marchena-Gomez [29] shows that adventure tourism is grouped into three aspects: those tourists who occasionally intervene in nature, those who seek a challenge and require natural spaces, and, finally, those tourists who contemplate nature.

Taking Buckley's suggestions into account [30], he tries to point out, among his research priorities, aspects such as knowing the characteristics of the client and the influence of demographic factors, the activities and social impacts related to adventure tourism, and the links between adventure tourism and lifestyle.

Therefore, the current study aims to know the socio-demographic characteristics of tourists who choose to do adventure tourism. Knowing the profile of this type of adventurous tourist will give us important information to provide the appropriate services and understand the methods they use to act on the impact they leave on the ecosystem. With this information, the second aim of this study will be to know what type of adventure tourist uses which means of transport.

\section{Materials and Methods}

\subsection{Participants}

The sample for this study is composed of 380 people who do adventure sports, whose average age is 37.62 years. 


\subsection{Methods}

The data collection was obtained through the information source of the National Institute of Statistics (INE) of the year 2019. The INE takes the necessary logical, physical, and administrative measures to ensure that the protection of confidential data is effective, guaranteeing the anonymity of the data collected from the survey. A total of 380 national and international tourists were interviewed, which opted for adventure tourism. In this way, an attempt was made to identify groups of tourists who consumed a certain tourist resource, according to the activities they carried out to find out the purpose, motivation for the trip, and its characteristics. The variables for the study taken from the surveys analyzed were age, nationality, marital status, cohabitation with a partner, level of studies, economic activity, the professional status in the job performed, type of household, location of secondary housing, type of accommodation and main means of transport.

\subsection{Statistics}

Analysis of the collected data was performed with the Statistical Package for Social Sciences (SPSS) version 23.0.

The Kolmogorov-Smirnov test allows for measurement of the degree of agreement between the distribution of a dataset and specific theoretical distribution. Therefore, this test was performed to show the distribution of the data in the age variable. It was then found that the data did not fit a normal distribution. Therefore, to check if there were statistically significant differences between men and women in this variable, the non-parametric Mann-Whitney U test was performed.

To check if there were significant gender differences, both in the ordinal and nominal variables, a contingency table was made using Chi-square. The significance level for all statistical tests was set at $p<0.05$.

\section{Results}

Firstly, the Kolmogorov-Smirnov test was performed to show the distribution of the data in the age variable of the sample. Thus, the obtained results show that the distribution is not normal, being $<0.001$.

Secondly, Table 1 shows the age of participants segregated by gender. This first variable shown indicates that the median age of the participants is 40.00, $39.00 \mathrm{in}$ men, and with an IQR of 20.00 for the whole sample. Likewise, Figure 1 is also provided to show the age distribution of adventure tourists in the sample.

Table 1. Age of study participants.

\begin{tabular}{ccccc}
\hline Age (Years) & Total & Men & Women & $p$ \\
\hline Median (IQR) & $40.00(20.00)$ & $39.00(20.00)$ & $40.00(20.00)$ & 0.882 \\
\hline $\begin{array}{l}p=\text { Mann-Whitney U test has been analyzed to show if there are differences between the variables in men and } \\
\text { women participating in the study. }\end{array}$
\end{tabular}

In this way, the null hypothesis that arises for these data establishes that the sample will have a normal distribution in the age of the participants. However, the alternative hypothesis establishes that the sample will not have a normal distribution. Performing the Kolmogorov-Smirnov test, it is shown that the distribution of the sample is not normal ( $p$ $<0.001$ ). Therefore, taking the median of the data in the Mann-Whitney U-test (Table 1) as a reference, a value of $p=0.882$ is shown, so that the differences found concerning the age of the participants are not statistically significant. Despite the existence of differences, the only 1-year difference in age between men and women is shown, as it is a sample without statistically significant differences in this variable.

In Table A1, the distribution of the variables under study are shown, with statistically significant differences between the numbers of people who have selected different responses in the following variables: level of studies (Figure 2), professional status in the job performed (Figure 3), and the type of accommodation (Figure 4). 


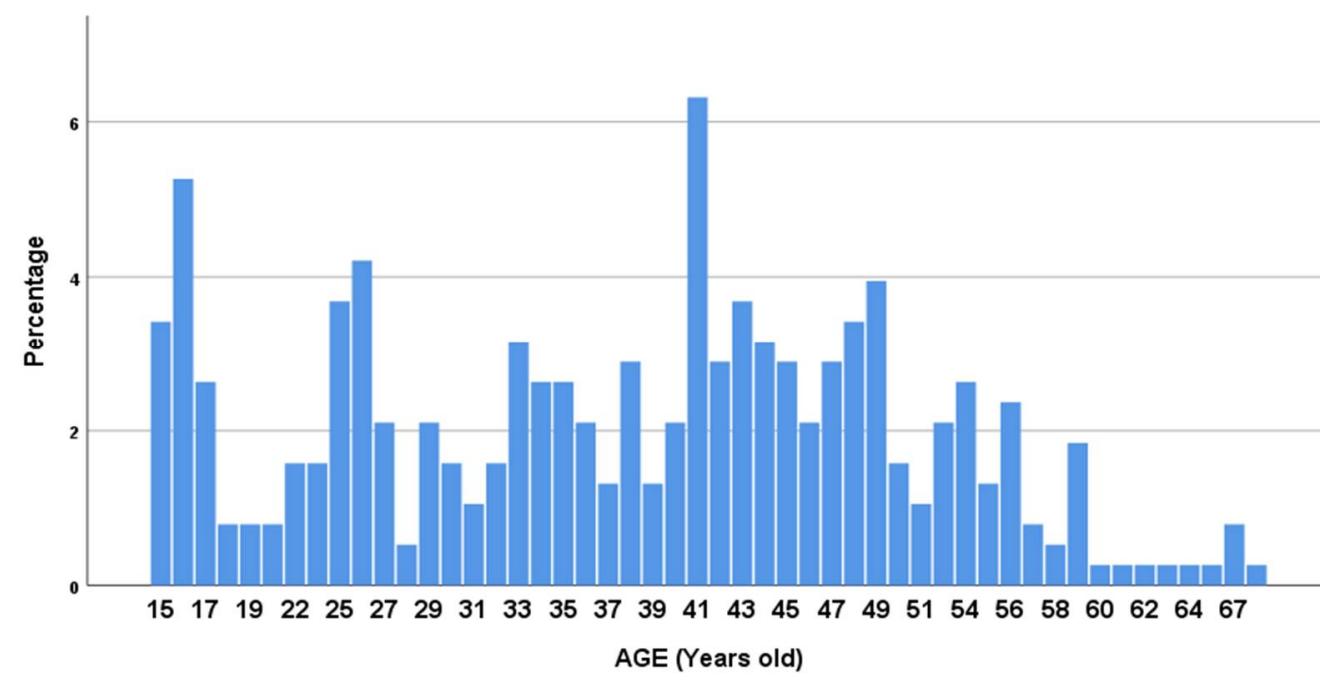

Figure 1. Age distribution of the sample.

Men

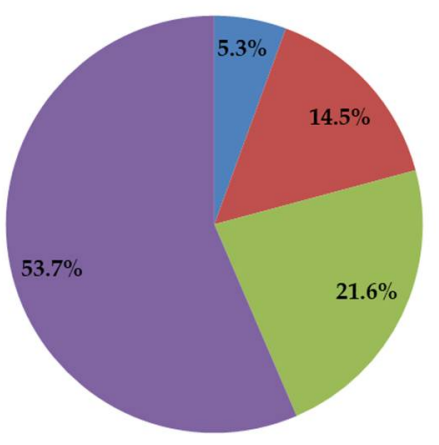

(a)

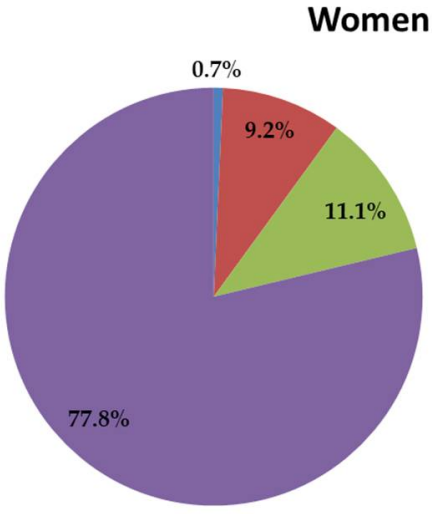

- Primary education or less

- Secondary education, first stage

- Secondary education,

second stage

- Post-secondary education

$p<0.001$

$p=$ Chi-square test

Figure 2. Significant statistical differences in the Level of Studies: (a) Distribution of frequencies of the variable level of studies in men; (b) Distribution of frequencies of the variable level of studies in women. Source: National Institute of Statistics (2019).

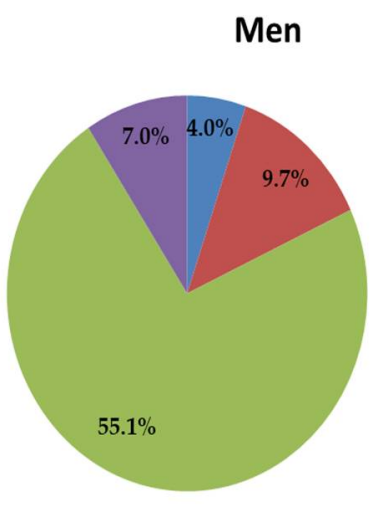

(a)

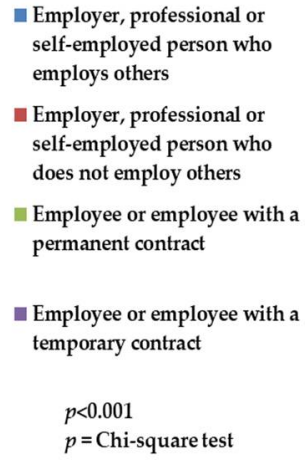
self-employed person who employs others

n Employer, professional or self-employed person who does not employ others

- Employee or employee with a permanent contract

Employee or employee with a temporary contract

$p<0.001$ $p=$ Chi-square test

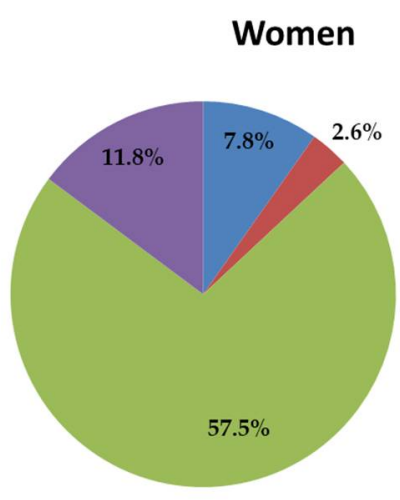

(b)

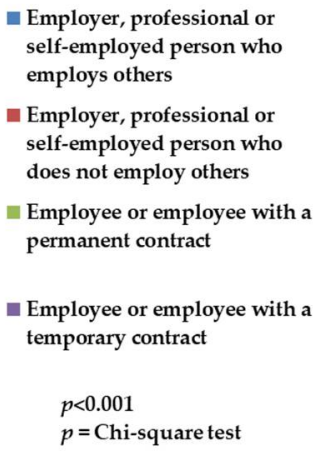

$p=$ Chi-square test

Figure 3. Significant statistical differences in the professional status in the job performed: (a) Distribution of frequencies of the variable professional status in the job performed in men; (b) Distribution of frequencies of the variable professional status in the job performed in women. Source: National Institute of Statistics (2019). 


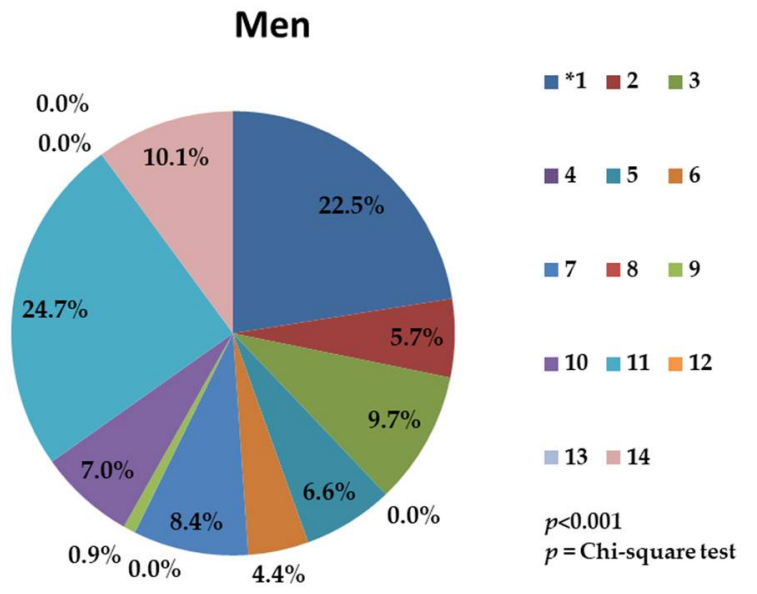

(a)

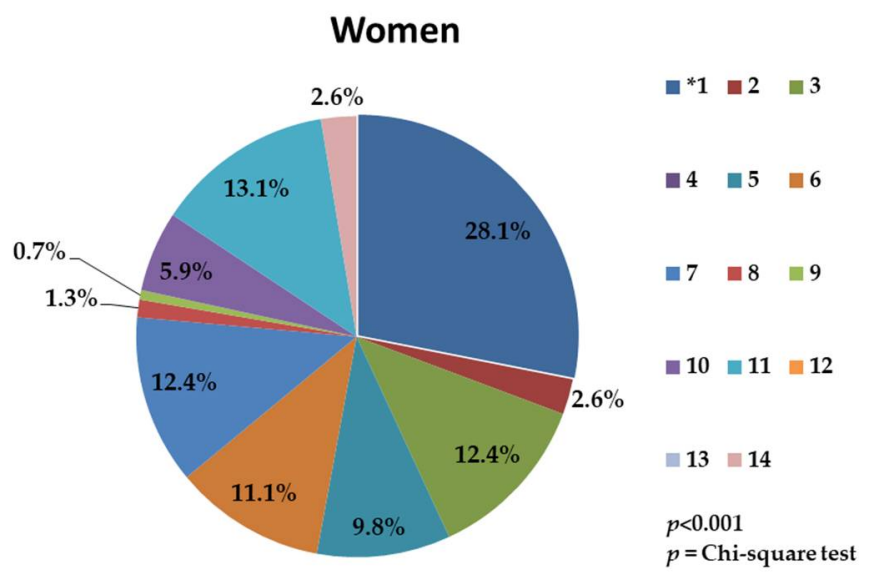

(b)

Figure 4. Significant statistical differences in the type of accommodation: (a) Distribution of frequencies of the variable type of accommodation in men; (b) Distribution of frequencies of the variable type of accommodation in women. Source: National Institute of Statistics (2019). * 1 = Hotel or apartment hotel; 2 = Hostel; 3 = Complete housing for rent; $4=$ Room for rent in a private home; $5=$ Rural tourism accommodation; $6=$ Shelter; $7=$ Camps; $8=$ Cruise; $9=$ Other market accommodations; 10 = Home ownership; 11 = Family, friend or company housing; 12 = Shared use housing; $13=$ Swapped homes; 14 = Other non-market accommodations.

The results in Table A1 inform about a profile of tourists of mature age, indicating a level of higher education in which they have experience (63.4\%). It can also identify a high percentage of single people opting for this type of tourism ( $50.8 \%$ ), followed by $39.5 \%$ of married people.

It can be shown that most of the participants are in active employment, with $77.4 \%$ of those interviewed stating that they were employed. Related to this, $56.1 \%$ of those surveyed are employees or employees with a permanent contract. More than half of the subjects (54.5\%) live in a couple with children cohabitating at home in terms of the type of accommodation. The majority of tourists (24.7\%) stated that they stayed in hotels or apartment hotels, followed by accommodation with family or friends or company housing (20\%).

In terms of the way they travel, a very high percentage (72.6\%) chose to use their car or other private cars that were owned or leased; air transport (15.8\%) was the second most frequent option and the bus is the third option, with $7.1 \%$. The least used means were ferry $(0.8 \%)$ and car or carpooling with payment to the driver $(0.3 \%)$. The most significant statistical differences were found in the variables of the level of studies $(p<0.001)$, professional status in the job performed $(p=0.01)$, and type of accommodation $(p<0.001)$.

Table A2 now shows the distribution of the different variables according to the means of transport used by the tourists. For this, the three main means of transport used will be extracted: air transport, private cars (including all types) and bus (public transport) to observe what profile of adventure tourist each means of transport uses.

Related to the obtained results, Table A2 shows which tourist profile uses air transport, private cars (including all types), and bus (public transport). Air transport is mainly used by single tourists $(8.2 \%)$, followed by married tourists $(5.5 \%)$. The results of tourists not cohabitating together as a couple $(8.2 \%)$, and tourists with the highest level of education $(13.4 \%)$ are also notable. These are employees or employees with permanent contract tourists $(11.2 \%)$, and they usually stay in hotels or apartment hotels $(6.6 \%)$. On the other hand, private cars are mainly used by single tourists (34.3\%), or married tourists $(32.7 \%)$. The percentage of tourists not cohabitating together as a couple (34.0\%) or cohabitating with their spouse (32.4\%), and tourists with the highest level of education $(48.2 \%)$ are also notable. These are employees or employees with permanent contract tourists (58.5\%) and they usually stay in hotels or apartment hotels $(16.3 \%)$ or family, friend, or company 
housing (15.5\%). Lastly, public transport (bus) is mainly used by only tourists of Spanish nationality $(7.1 \%)$ and by single tourists $(6.3 \%)$. Tourists that do not cohabitate together as a couple $(6.3 \%)$, and have a secondary education, or a first stage level of education (3.0\%) also showed noteworthy results. They are employees or employees who are temporary-contract tourists $(2.0 \%)$, and usually stay in shelters $(2.9 \%)$.

\section{Discussion}

The main finding of our study has been the description of the profile of the adventure tourist, segregating the data according to the gender variable, as well as knowing the means of transport used by this tourist profile.

Concerning general gender differences, the study of Mosquera González [31] shows gender as a variable for analyzing the practice of sport by women and men, referring to who does more or less sport. This is a question of respect for the different realities and cultures of each person and of demanding equal opportunities for women and men. However, the study by Hargreaves [32] states that there is gender discrimination in this field, which is very changeable and cannot remain unchanged.

Regarding the data obtained from our study regarding the sociodemographic profile of the adventure tourist (Table A1), they show and compare the results extracted from other studies on this subject. The study carried out by the Travel Industry of America [33], which shows that $16 \%$ of Americans had participated in adventure activities in the last five years, indicates that the profile of the adventure tourist is usually male, single, young, and with a university education, coinciding with our study in being single and in the highest level of study. However, in the study by Lötter et al. [20], it is indicated that typical adventure tourists in Pretoria are mostly married people with no children or two children over the age of twelve, and they also tend to be more highly trained Technical and Professional Associates. This coincides with the study of the profile of the adventure tourist in Peru [34], observing that the majority of tourists were executive professionals or technical professionals, as was the case in the previous study [20]. Likewise, the study by Mohamed et al. [21], analyzing the profile of adventure tourists in Kampar, shows that they have an average age of 33, an average monthly income of RM 3638.72, a university education, and that most of them travel with friends. By these variables, also Giddy's study [22] on tourists from South Africa shows that most participants are relatively young, but also include people over 40 years old, and that the number of women participating in high-adrenaline activities is increasing. The type of accommodation is highly variable, as indicated by Martín-Acebes and Ramón-Fernández [35], stating that the most demanded forms of accommodation are hotels, campsites, and country houses, or rural accommodation and hostels, according to Moral-Cuadra et al. [36], with, hotels, apartment hotels, and family or friends or company housing standing out in our study. Noting that private transport predominates in all of them, the study by Rojo-Ramos et al. [37] proposes means of public transport that are more accessible to tourists and more sustainable for the environment.

Regarding this last variable, Table A2 refers to the means of transport used by the previously analyzed profile of adventure tourists. Studies such as that of Gutiérrez and Miravet [23] show that, as in our study, tourists who used air transport tended to stay in hotels. Moreover, in their research, these were the ones who spent the most on their holidays. In that study, it is also shown that tourists who arrived by private car subsequently made the least use of public transport at the destination. To show the acquired importance of air transport, another study [38] shows that most of the international tourists who visited Spain in 2019 arrived by air transport, this being the second most chosen option by the adventure tourists of our study. In Spain, the most common means of transport used in nature tourism [39], as in our study, is the private vehicle. This characteristic reflects the preferential travel habits of tourists and the scarcity of transport alternatives, due to the rural nature of the areas where the activity takes place. Therefore, it is shown that, as in most studies and research on the subject, most travelers and tourists used a private car on their trips [40], as shown in Table A2. 
Some of the purposes of adventure tourism are shown in the study of Bui and Kiatkawsin [41]. These are understood to be seeking unfamiliar places, meeting unfamiliar people, to explore and study, or for recreation. Consequently, adventure tourism is a large but little-studied sector, that has yet to identify future priorities. Some authors, like Buckley [30], point out that the main topics in the research into adventure recreation have been psychological, focusing on the reasons why people get involved in adventure activities and their experiences. He also suggests studies that highlight the characteristics of clients or the links of adventure tourism with lifestyles and their impact on the environment, among others.

In the Minotta study [42], reference is made to the young tourist, who they show similar characteristics to our study in terms of interest in nature care and the use of social networks for their travel plans. This profile of young tourism drives innovation, due to the challenges they must face every day, expressing valuable experiences and even perceiving them as key moments in their lives. Along these lines, Carvache-Franco [43] shows a questionnaire that sought to find a model for the creation of adventure tourism packages. Through this, the aim is to satisfy the needs of tourists and improve the product offer in a destination that has natural resources for the development of this type of tourism.

Regarding the results of the adventure tourist profile, some investigations showed similar characteristics, where the possibility of having many unique experiences is offered. These allow the tourist to enjoy the ecosystem for those whose main motivation for the trip is the surrounding natural environment or environments, either for contemplation, protection, or conservation of the ecosystem [44]. Along the same lines, the study by Leco et al. [45], indicates that the presence of an environment in its correct natural state represents a unique special attraction for tourists who have a preference for this type of tourism.

Likewise, and related to this, it is considered that adventure tourism is a particularly attractive type of tourism for tourists who are looking for a direct connection with nature and are involved in sustainable development. In this way, they seek separation from the stressful movements that cities and their active daily life can cause them [46]. This is shown in the Giddy and Webb study [47], which evaluates the motivations of adventure tourists, showing that the environment plays an important role in attracting these tourists, as they also seek interactions with nature. Besides, their participants suggested that the environment is a particularly significant component of their experiences.

However, the work carried out by Muñoz et al. [48] on adventure tourism and its environmental impact specifies that through some activities, such as trekking, their natural resources have been seriously affected. The soil is quite affected by adventure tourism and the environmental impact is directly related to the activity. Similarly, the study by Tinoco [49] shows the impacts generated by adventure tourism, not only environmental and economic but also social and cultural, with nature as the main setting and where tourism and conservation often come into conflict. These impacts are related to our results on the use of private cars and air transport in adventure tourism, and the corresponding pollution and lack of sustainability. The differences found in the study of Gutierrez and Miravet [23] between tourists who arrive by private car and those who use other means of transport lead to the identification of this group as a clear target for promoting policies in favor of the use of public transport in this type of natural destination.

On the one hand, the study of Blanco and Benayas [50] communicates the impact caused by tourists in a natural environment. This is not only of a physical nature, but also involves a social burden. Thus, one could understand the sense of burden experienced by tourists visiting a place and meeting a large number of visitors. Thus, the tourist's experience tends to be valued negatively regardless of the place visited. On the other hand, regarding the perception of the local people of settlement in protected areas, it is clear that they were established to satisfy foreign interests before their own [51]. 
Thus, the study by Nicolau [52] analyses the determining factors in the cultural motivation of tourists when choosing a destination. This study concludes that a high cultural motivation when deciding on a destination is related to a high level of education, a search for new knowledge, a small home, and a great interest in getting to know different places.

After having analyzed the profile of the adventure tourist, it is important to provide information to improve the footprint and impact of human presence in nature. Together with the sustainable development goals [24], the aim is that everyone can prosper and strengthen their skills, conserving the good that each human being has, the places, and the planet so that, in this way, it is possible to continue and bet on a healthier ecosystem. Thus, it will be easier to achieve the proposed goals if all sectors are involved, such as governments or institutions. In general, we all commit to helping the planet become cleaner and healthier by 2030 and, through science, technology, and innovation, we can make great contributions towards the achievement of these sustainable development goals [53].

For this reason, through this study, we try to show a series of effective implications for sustainability through adventure tourism according to the data found, to the our best of our knowledge, to date. A considerable increase has been observed in the degradation of natural resources and the most popular tourist destinations, all as a result of the uncontrolled actions of tourists [54]. As tourism is a sector strongly influenced by the permanent changes that take place in the activity and the surrounding environment [55], with our study, we try to achieve adequate and strategic planning to improve the quality of the activities offered. As we have indicated, the use of public transport, which is more accessible and less polluting, should be promoted instead of cars and planes, which cause a high visual impact and high levels of pollution. To continue with this correct development, the determination of tourism-carrying capacity is also presented as an effective instrument for the mitigation of environmental problems, the conservation of the natural and cultural heritage, and the development of tourism in a territory. Likewise, it is considered necessary to promote the inclusion of activities that are congruent with the environment, participatory and, especially responsible, sufficiently malleable and that can be replicated in different territories [54]. In this way, some studies, such as Mateos et al. [56], indicate that it would be advisable for all-natural protected areas to have a management and participation body responsible for organizing and evaluating the degree of tourism sustainability in the protected area.

Continuing with these action implications, this study provides information and the development of optimal variables to improve the quality of the tourism experience. Thereby, it will enable the management of the carrying capacity of tourism and guarantee the conservation of natural resources. All these implications and actions are related to the sustainable development goals [24], to obtain mechanisms of environmental protection and extend the conservation of these natural areas. Furthermore, considering these adventure activities as a form of sustainable tourism will have a positive impact on tourists, showing their importance and a greater understanding and commitment to sustainability.

It is interesting to be able to reflect on the limitations we have encountered in carrying out the research, to take them into account in future studies. One of the main limitations has been the small size of the sample and its lack of representativeness, since it is the sample of respondents who opted for adventure tourism, a small percentage of the total number of respondents. Another limitation we have encountered has been the lack of exact information about the place of departure and the destination of the tourism activity carried out by the participants, since, with this information, we could know the carbon footprint left by each tourist in more detail, and draw up proposals for more sustainable practices that go hand-in-hand with this type of adventure tourism. 
Taking the present study into account, it is necessary that, in the future, the profile of the adventure activities tourist be deepened, to know which their main activities are and how they relate sustainably with nature. It is important and necessary to give continuity to the present study with future works that can represent concrete support of the decisions of the tourist agencies. Understanding these preferences can be of great help to the tourist offer, trying to go in the same direction as consumers and lead to conservation and improvement in the environment.

\section{Conclusions}

The main conclusions of this research aim to be helpful in providing appropriate services and understanding the methods needed to mitigate the impact that these types of activities may have on the ecosystem.

To summarize, and once the variables included in the study have been analyzed, the socio-demographic profile of the adventure tourist can be identified. Thus, the majority of profiles correspond to single people with a higher educational level and a stable professional situation. Likewise, the most-used means of transport is their car or other private cars owned or leased followed by air transport, and the majority choose hotels or apartment hotels as their favorite accommodation, followed very closely by accommodation with family or friends or company housing. Finally, the most significant statistical differences were found in the variables of the level of study, professional status in the job performed, and type of accommodation, taking into account the gender of the participants.

Analyzing the main means of transport used, it is shown that the private car is the one chosen by the majority of participants, followed by air transport and, finally, by public transport (bus). The profile of the adventure tourist is quite similar in all three cases, being a single or married tourist, that do not cohabitate together as a couple or cohabitation with their spouse, with the highest level of education. They are usually employees or employees with a permanent contract and staying in hotels or apartment hotels.

Thereby, this study aims to show the relevance of knowing the profile and sociodemographic characteristics of the adventure tourist to be able to provide the most appropriate services and products. At the same time, it aims to make known the implications and necessary mechanisms of environmental protection and conservation of natural areas, increasing the commitment to sustainability through adventure tourism.

Author Contributions: Conceptualization, J.R.-R., R.P.P.-C., C.G.-A., F.M.-R., and J.C.A.; formal analysis, J.R.-R., R.P.P.-C., C.G.-A., and J.C.A.; funding acquisition, R.G.-C., R.V.-E.; methodology, J.R.-R., R.P.P.-C., C.G.-A., F.M.-R., and J.C.A.; software, J.R.-R., R.P.P.-C., C.G.-A., F.M.-R., and J.C.A.; writing-original draft, J.R.-R., R.P.P.-C., C.G.-A., F.M.-R., and J.C.A.; writing-review and editing, J.R.-R., R.P.P.-C., C.G.-A., F.M.-R., and J.C.A. All authors have read and agreed to the published version of the manuscript.

Funding: This research received no external funding.

Institutional Review Board Statement: Not applicable.

Informed Consent Statement: Not applicable.

Data Availability Statement: Source: National Institute of Statistics (2019).

Conflicts of Interest: The authors declare no conflict of interest. 


\section{Appendix A}

Table A1. Frequency distribution of the variables under study.

\begin{tabular}{|c|c|c|c|c|}
\hline & Total & Men & Women & $\mathbf{p}$ \\
\hline Nationality & $\mathbf{N}(\%)$ & $\mathbf{N}(\%)$ & N (\%) & \multirow{4}{*}{0.94} \\
\hline Only Spanish & $369(97.1)$ & $220(96.9)$ & $149(97.4)$ & \\
\hline Only Foreign & $5(1.3)$ & $3(1.3)$ & $2(1.3)$ & \\
\hline Spanish and Foreign & $6(1.6)$ & $4(1.8)$ & $2(1.3)$ & \\
\hline Marital status & $\mathbf{N}(\%)$ & N (\%) & N (\%) & \multirow{6}{*}{0.49} \\
\hline Single & $193(50.8)$ & $117(51.5)$ & $76(49.7)$ & \\
\hline Married & $150(39.5)$ & $85(37.4)$ & $65(42.5)$ & \\
\hline Widowed & $3(0.8)$ & $1(0.4)$ & $2(1.3)$ & \\
\hline Separate & $5(1.3)$ & $4(1.8)$ & $1(0.7)$ & \\
\hline Divorced & $29(7.6)$ & $20(8.8)$ & $9(5.9)$ & \\
\hline Cohabitation with a Partner & $\mathbf{N}(\%)$ & $\mathbf{N}(\%)$ & N (\%) & \multirow{4}{*}{0.61} \\
\hline Cohabitation with their spouse & $146(38.4)$ & $85(37.4)$ & $61(39.9)$ & \\
\hline Cohabitation with a common-law partner & $42(11.1)$ & $23(10.1)$ & $19(12.4)$ & \\
\hline Not cohabitation together as a couple & $192(50.5)$ & $119(52.4)$ & $73(47.7)$ & \\
\hline Level of studies & $\mathbf{N}(\%)$ & $\mathbf{N}(\%)$ & N (\%) & \multirow{6}{*}{$<0.001$} \\
\hline Primary education or less & $13(3.4)$ & $12(5.3)$ & $1(0.7)$ & \\
\hline Secondary education, first stage & $47(12.4)$ & $33(14.5)$ & $14(9.2)$ & \\
\hline Secondary education, second stage & $66(17.4)$ & $49(21.6)$ & $17(11.1)$ & \\
\hline Post-secondary education & $241(63.4)$ & $122(53.7)$ & $119(77.8)$ & \\
\hline Missing values & $13(3.4)$ & $11(4.8)$ & $2(1.3)$ & \\
\hline Relationship between economic activity & $\mathbf{N}(\%)$ & $\mathbf{N}(\%)$ & $\mathbf{N}(\%)$ & \multirow{6}{*}{0.57} \\
\hline Employed & $294(77.4)$ & $172(75.8)$ & $122(79.7)$ & \\
\hline Unemployed & $18(4.7)$ & $9(4.0)$ & $9(5.9)$ & \\
\hline Retired & $9(2.4)$ & $7(3.1)$ & $2(1.3)$ & \\
\hline Other inactive & $46(12.1)$ & $28(12.3)$ & $18(11.8)$ & \\
\hline Missing values & $13(3.4)$ & $11(4.8)$ & $2(1.3)$ & \\
\hline Professional status in the job performed & $\mathbf{N}(\%)$ & $\mathbf{N}(\%)$ & $\mathbf{N}(\%)$ & \multirow{6}{*}{0.01} \\
\hline $\begin{array}{l}\text { Employer, professional or self-employed person who } \\
\text { employs others }\end{array}$ & $21(5.5)$ & $9(4.0)$ & $12(7.8)$ & \\
\hline $\begin{array}{l}\text { Employer, professional or self-employed person who does } \\
\text { not employ others }\end{array}$ & $26(6.8)$ & $22(9.7)$ & $4(2.6)$ & \\
\hline Employee or employee with a permanent contract & $213(56.1)$ & $125(55.1)$ & $88(57.5)$ & \\
\hline Employee or employee with a temporary contract & $34(8.9)$ & $16(7.0)$ & $18(11.8)$ & \\
\hline Missing values & $86(22.6)$ & $55(24.2)$ & $31(20.3)$ & \\
\hline Type of household & $\mathbf{N}(\%)$ & $\mathbf{N}(\%)$ & $\mathbf{N}(\%)$ & \multirow{6}{*}{0.24} \\
\hline Single household & $51(13.4)$ & $36(15.9)$ & $15(9.8)$ & \\
\hline Single parent cohabitation with a child & $45(11.8)$ & $22(9.7)$ & $23(15.0)$ & \\
\hline Couple without children cohabitation at home & $60(15.8)$ & $38(16.7)$ & $22(14.4)$ & \\
\hline Couple with children cohabitation at home & $207(54.5)$ & $122(53.7)$ & $85(55.6)$ & \\
\hline Other household & $17(4.5)$ & $9(4.0)$ & $8(5.2)$ & \\
\hline Location of secondary housing & $\mathbf{N}(\%)$ & $\mathbf{N}(\%)$ & $\mathbf{N}(\%)$ & \multirow{3}{*}{0.85} \\
\hline Spain & $95(25.0)$ & $56(24.7)$ & $39(25.5)$ & \\
\hline Foreign country & $285(75.0)$ & $171(75.3)$ & $114(74.5)$ & \\
\hline Type of Accommodation & $\mathbf{N}(\%)$ & $\mathbf{N}(\%)$ & $\mathbf{N}(\%)$ & \multirow{7}{*}{$<0.001$} \\
\hline Hotel or apartment hotel & $94(24.7)$ & $51(22.5)$ & $43(28.1)$ & \\
\hline Hostel & $17(4.5)$ & $13(5.7)$ & $4(2.6)$ & \\
\hline Complete housing for rent & $41(10.8)$ & $22(9.7)$ & $19(12.4)$ & \\
\hline Room for rent in a private home & - & - & - & \\
\hline Rural tourism accommodation & $30(7.9)$ & $15(6.6)$ & $15(9.8)$ & \\
\hline Shelter & $27(7.1)$ & $10(4.4)$ & $17(11.1)$ & \\
\hline
\end{tabular}


Table A1. Cont.

\begin{tabular}{|c|c|c|c|c|}
\hline & Total & Men & Women & $\mathrm{p}$ \\
\hline Camps & $38(10.0)$ & $19(8.4)$ & $19(12.4)$ & \\
\hline Cruise & $2(0.5)$ & - & $2(1.3)$ & \\
\hline Other market accommodations & $3(0.8)$ & $2(0.9)$ & $1(0.7)$ & \\
\hline Home ownership & $25(6.6)$ & $16(7.0)$ & $9(5.9)$ & \\
\hline Family, friend or company housing & $76(20.0)$ & $56(24.7)$ & $20(13.1)$ & \\
\hline Shared use housing & - & - & - & \\
\hline Swapped homes & - & - & - & \\
\hline Other non-market accommodations & $27(7.1)$ & $23(10.1)$ & $4(2.6)$ & \\
\hline Main means of transport & $\mathbf{N}(\%)$ & $\mathbf{N}(\%)$ & $\mathbf{N}(\%)$ & \\
\hline Air transport & $60(15.8)$ & $34(15.0)$ & $26(17.0)$ & \\
\hline Cruise & - & - & - & \\
\hline Ferry & $3(0.8)$ & - & $3(2.0)$ & \\
\hline Own, leased or rented boat & - & - & - & 0.30 \\
\hline Car or other private cars owned or leased & $276(72.6)$ & $169(74.4)$ & $107(69.9)$ & \\
\hline $\begin{array}{l}\text { Car or other private cars rented without a driver from rental } \\
\text { companies }\end{array}$ & $5(1.3)$ & $4(1.8)$ & $1(0.7)$ & \\
\hline Taxis or carpooling with payment to the driver & - & - & - & \\
\hline Car or carpooling with payment to the driver & $1(0.3)$ & $1(0.4)$ & - & \\
\hline Bus & $27(7.1)$ & $14(6.2)$ & $13(8.5)$ & \\
\hline Train & $8(2.1)$ & $5(2.2)$ & $3(2.0)$ & \\
\hline Non-motorized land transport & - & - & - & \\
\hline
\end{tabular}

$p=$ Chi-square test has been analyzed to show if there are differences between the variables in men and women participating in the study.

Table A2. Distribution of variables according to means of transport.

\begin{tabular}{|c|c|c|c|}
\hline Variable & Air transport & Private cars & Bus \\
\hline Nationality & N (\%) & $\mathbf{N}(\%)$ & $\mathbf{N}(\%)$ \\
\hline Only Spanish & $55(14.5)$ & $276(72.7)$ & $27(7.1)$ \\
\hline Only Foreign & $3(0.8)$ & $2(0.5)$ & $0(0)$ \\
\hline Spanish and Foreign & $2(0.5)$ & $4(1.1)$ & $0(0)$ \\
\hline Marital status & $\mathbf{N}(\%)$ & N (\%) & $\mathbf{N}(\%)$ \\
\hline Single & $31(8.2)$ & $130(34.3)$ & $24(6.3)$ \\
\hline Married & $21(5.5)$ & $124(32.7)$ & $3(0.8)$ \\
\hline Widowed & $2(0.5)$ & $0(0)$ & $0(0)$ \\
\hline Separate & $1(0.3)$ & $4(1.1)$ & $0(0)$ \\
\hline Divorced & $5(1.3)$ & $24(6.3)$ & $0(0)$ \\
\hline Cohabitation with a Partner & $\mathbf{N}(\%)$ & N (\%) & $\mathbf{N}(\%)$ \\
\hline Cohabitation with their spouse & $19(5.0)$ & $123(32.4)$ & $3(0.8)$ \\
\hline Cohabitation with a common-law partner & $10(2.6)$ & $30(7.9)$ & $0(0)$ \\
\hline Not cohabitation together as a couple & $31(8.2)$ & $129(34.0)$ & $24(6.3)$ \\
\hline Level of studies & $\mathbf{N}(\%)$ & $\mathbf{N}(\%)$ & $\mathbf{N}(\%)$ \\
\hline Primary education or less & $0(0)$ & $12(3.3)$ & $1(0.3)$ \\
\hline Secondary education, first stage & $3(0.8)$ & $33(9.0)$ & $11(3.0)$ \\
\hline Secondary education, second stage & $8(2.2)$ & $51(13.9)$ & $2(0.5)$ \\
\hline Post-secondary education & $49(13.4)$ & $177(48.2)$ & $9(2.5)$ \\
\hline Relationship between economic activity & $\mathbf{N}(\%)$ & $\mathbf{N}(\%)$ & $\mathbf{N}(\%)$ \\
\hline Employed & $50(13.6)$ & $226(61.6)$ & $8(2.2)$ \\
\hline Unemployed & $2(0.5)$ & $15(4.1)$ & $1(0.3)$ \\
\hline Retired & $3(0.8)$ & $5(1.4)$ & $0(0)$ \\
\hline Other inactive & $5(1.4)$ & $27(7.4)$ & $14(3.8)$ \\
\hline
\end{tabular}


Table A2. Cont.

\begin{tabular}{|c|c|c|c|}
\hline Variable & Air transport & Private cars & Bus \\
\hline Professional status in the job performed & $\mathbf{N}(\%)$ & $\mathbf{N}(\%)$ & $\mathbf{N}(\%)$ \\
\hline Employer, professional or self-employed person who employs others & $3(1.0)$ & $15(5.1)$ & $0(0)$ \\
\hline Employer, professional or self-employed person who does not employ others & $9(3.1)$ & $17(5.7)$ & $0(0)$ \\
\hline Employee or employee with a permanent contract & $33(11.2)$ & $172(58.5)$ & $2(0.7)$ \\
\hline Employee or employee with a temporary contract & $5(1.7)$ & $22(7.5)$ & $6(2.0)$ \\
\hline Type of household & $\mathbf{N}(\%)$ & $\mathbf{N}(\%)$ & $\mathbf{N}(\%)$ \\
\hline Single household & $8(2.1)$ & $39(10.3)$ & $3(0.8)$ \\
\hline Single parent cohabitation with a child & $13(3.4)$ & $26(6.9)$ & $5(1.3)$ \\
\hline Couple without children cohabitation at home & $11(2.9)$ & $46(12.1)$ & $1(0.3)$ \\
\hline Couple with children cohabitation at home & $25(6.6)$ & $159(41.8)$ & $17(4.5)$ \\
\hline Other household & $3(0.8)$ & $12(3.2)$ & $1(0.3)$ \\
\hline Location of secondary housing & $\mathbf{N}(\%)$ & $\mathbf{N}(\%)$ & $\mathbf{N}(\%)$ \\
\hline Spain & $10(2.6)$ & $78(20.5)$ & $6(1.6)$ \\
\hline Foreign country & $50(13.2)$ & $204(53.7)$ & $21(5.5)$ \\
\hline Type of Accommodation & $\mathbf{N}(\%)$ & $\mathbf{N}(\%)$ & $\mathbf{N}(\%)$ \\
\hline Hotel or apartment hotel & $24(6.3)$ & $62(16.3)$ & $6(1.6)$ \\
\hline Hostel & $5(1.3)$ & $10(2.6)$ & $2(0.5)$ \\
\hline Complete housing for rent & $10(2.6)$ & $30(7.9)$ & $0(0)$ \\
\hline Room for rent in a private home & $0(0)$ & $0(0)$ & $0(0)$ \\
\hline Rural tourism accommodation & $3(0.8)$ & $26(6.8)$ & $1(0.3)$ \\
\hline Shelter & $3(0.8)$ & $12(3.2)$ & $11(2.9)$ \\
\hline Camps & $3(0.8)$ & $31(8.1)$ & $4(1.1)$ \\
\hline Cruise & $2(0.5)$ & $0(0)$ & $2(1.3)$ \\
\hline Other market accommodations & $0(0)$ & $3(0.8)$ & $0(0)$ \\
\hline Home ownership & $0(0)$ & $25(6.6)$ & $0(0)$ \\
\hline Family, friend or company housing & $8(2.1)$ & $59(15.5)$ & $2(0.5)$ \\
\hline Shared use housing & $0(0)$ & $0(0)$ & $0(0)$ \\
\hline Swapped homes & $0(0)$ & $0(0)$ & $0(0)$ \\
\hline Other non-market accommodations & $2(0.5)$ & $24(6.4)$ & $1(0.3)$ \\
\hline
\end{tabular}

$p=$ Chi-square test has been analyzed to show if there are differences between the variables in men and women participating in the study.

\section{References}

1. Rojo, I.M. Dirección y Gestión de Empresas del Sector Turístico; Ediciones Pirámide: Madrid, Spain, 2020.

2. Agüera, F.O. El turismo comunitario como herramienta para el desarrollo sostenible de destinos subdesarrollados. Nómadas. Crit. J. Soc. Jurid. Sci. 2013, 38, 42908.

3. Fernández, J.F. El turismo sostenible en España: Análisis de los planes estratégicos de sostenibilidad de Zaragoza y Barcelona. ROTUR Rev. Ocio Tur. 2020, 14, 94-106. [CrossRef]

4. Yasumara, K. The Sociological Sphere of Tourism as A Social Phenomenon. 2011. Available online: https://www.academia.edu/ 2262641/The_Sociological_Sphere_of_Tourism_as_a_Social_Phenomenon (accessed on 16 December 2020).

5. Glaesser, D. Crisis Management in the Tourism Industry; Routledge: Abingdon, UK, 2006.

6. Moreno, M.C.M. Análisis de la calidad del servicio hotelero mediante la Escala de SERVQUAL Caso: Hoteles de Turismo del Municipio Libertador del Estado Mérida. Visión Gerenc. 2007, 6, 269-297.

7. Dziubinski, Z.; Jasny, M. Free time, tourism and recreation: Some sociological reflections. Ido Mov. Cult. J. Martial Arts Anthropol. 2017, 17, 68-73.

8. Włoch, R. Two dynamics of globalization in the context of a sports mega-event: The case of Uefa Euro 2012 in Poland. Globalizations 2020, 17, 45-59. [CrossRef]

9. Roberts, L.; Hall, D. Rural Tourism and Recreation: Principles to Practice; Cabi: Wallingford, UK, 2001.

10. Sung, H.; Morrison, A.; O’Leary, J. Turismo de Aventura. 1996. Available online: http://www.turismoaventura.com/comunidad/ contenidos/defTA/index.html (accessed on 16 December 2020).

11. Daly, J.; Goodland, R.; Serafy, S.; Droste, B. Medio ambiente y desarrollo sostenible. Brundtland 1997, 33 , 1-133.

12. Sancho, A.; Buhalis, D. Introducción al turismo. Madr. Organ. Mund. Tur. 1998, 392.

13. Cañaveral, I.P.; Prados, J.L.P. Ecoturismo, sostenibilidad y comunidad local. Available online: https://www.researchgate.net/ profile/Pedro_Ernesto_Moreira_Gregori/publication/324124228_TURISMO_Y_SOCIEDAD_EN_ANDALUCIA/links/5abf6 4e3aca27222c7583136/TURISMO-Y-SOCIEDAD-EN-ANDALUCIA.pdf\#page=306 (accessed on 16 December 2020). 
14. Delgado, J. Turismo Responsable: Una visión homeostática. 2004. Available online: https://www.ecoportal.net/temas-especiales/ desarrollo-sustentable/turismo_responsable_una_vision_homeostatica / (accessed on 16 December 2020).

15. Blasco, M.C. Turismo, identidad y reivindicación sociocultural en Chile. Tur. sostenibilidad: V Jorn. Investig. Tur. 2012, 2012, 127-145.

16. Association, A.T.T. Adventure Tourism Market Study 2013; Adventure Travel Trade Association and the George Washington University: Monroe, WA, USA, 2013; pp. 1-15.

17. Rantala, O.; Rokenes, A.; Valkonen, J. Is adventure tourism a coherent concept? A review of research approaches on adventure tourism. Ann. Leis. Res. 2018, 21, 539-552. [CrossRef]

18. Cheng, M.; Edwards, D.; Darcy, S.; Redfern, K. A tri-method approach to a review of adventure tourism literature: Bibliometric analysis, content analysis, and a quantitative systematic literature review. J. Hosp. Tour. Res. 2018, 42, 997-1020. [CrossRef]

19. Sand, M.; Gross, S. Tourism research on adventure tourism-Current themes and developments. J. Outdoor Recreat. Tour. 2019, 28, 100261. [CrossRef]

20. Lötter, M.J.; Geldenhuys, S.; Potgieter, M. Demographic profile of adventure tourists in Pretoria. Glob. J. Bus. Res. 2012, 6, 97-109.

21. Mohamed, Z.; Afandi, S.H.M.; Ramachandran, S.; Shuib, A.; Kunasekaran, P. Adventure Tourism in Kampar, Malaysia: Profile and Visit Characteristics of Domestic Visitors. Int. J. Bus. Soc. 2018, 19, 175-185.

22. Giddy, J.K. A profile of commercial adventure tourism participants in South Africa. Anatolia 2018, 29, 40-51. [CrossRef]

23. Gutiérrez, A.; Miravet, D. The determinants of tourist use of public transport at the destination. Sustainability 2016, 8, 908. [CrossRef]

24. Sostenible, D. Objetivos de Desarrollo Sostenible; Food and Agriculture Organization: Rome, Italy, 1986.

25. Turístico, E. ¿Qué es el Turismo de Aventura? Hablemos de Turismo: Guadalajara, Mexica, 2019.

26. Gil, C.G. Objetivos de Desarrollo Sostenible (ODS): Una revisión crítica. Pap. Relac. Ecosociales Cambio Glob. 2018, 140, 107-118.

27. Montes, M.E.G.; Juan, F.R. Actas del IV Congreso Internacional de Educación Física e Interculturalidad. El Deporte Unión de Culturas [CD ROM]. In El Ocio y la Recreación Físicodeportiva en la Sociedad Española Actual; Universidad de Murcia: Cancún, Mexican, 2004.

28. Sauvé, L. Environmental education: Possibilities and constraints. Educ. Pesqui. 2005, 31, 317-322. [CrossRef]

29. Rebollo, J.F.V.; Gómez, M.J.M. Efectos del turismo en las estructuras regionales periféricas: Una aproximación analítica. Millars Espai Hist. 1998, 21, 109-144.

30. Buckley, R. Adventure tourism research: A guide to the literature. Tour. Recreat. Res. 2006, 31, 75-83. [CrossRef]

31. González, M.J.M. ¿Las mujeres no hacen deporte porque no quieren? ¿ Los hombres practican el deporte que quieren? El género como variable de análisis de la práctica deportiva de las mujeres y de los hombres; Universidade da Coruña: Coruña, Spain, 2014.

32. Hargreaves, J. Sporting Females: Critical Issues in the History and Sociology of Women's Sport; Routledge: London, UK, 2002.

33. Naida, N.; Shaw, C.; Cook, S.D. The Adventure Travel Report, 1997; Travel Industry Association of America: Washington, DC, USA, 1998.

34. Seminario, M.M. Perfil del Turista de Aventura. 2008. Available online: www.promperu.gob.pe/turismoIN (accessed on 16 December 2020).

35. Acebes, A.S.M.; Fernández, F.R. Estudio comparativo de empresas de turismo de aventura de la provincia de Valencia. Gran Tour Rev. Investig. Turísticas 2011, 3, 51-68.

36. Cuadra, S.M.; Morales, P.C.; Agüera, F.O. El turismo de aventura: Concepto, evolución, características y mercado meta. El caso de Andalucía. Tur. Innovación VI Jorn. Investig. Tur. 2013, 2013, 327-343.

37. Ramos, J.R.; Carmona, R.M.; Arroyo, C.G.; Redondo, F.M.; Gordillo, M.Á.G.; Adsuar, J.C. Trekking tourism in spain: Analysis of the sociodemographic profile of trekking tourists for the design of sustainable tourism services. Sustainability 2020, $12,9113$. [CrossRef]

38. de Barcelona, A. Barcelona Tourism for 2020: A Collective Strategy for Sustainable Tourism; Tourism Department Manager's Office for Enterprise and Tourism: Barcelona, Spain, 2017.

39. González, M.L. Parques Nacionales en España. Comparación y Atractivos Turísticos; Universidad de Jaén: Jaén, Spain, 2020.

40. Talaya, Á.E.; Romero, C.L.; Martínez, M.E.A.; del Amo, M.d.C.A. ¿ Conocemos a los visitantes de Castilla-La Mancha? Un análisis comparativo turistas vs. excursionistas. PASOS Rev. Tur. Patrim. Cult. 2011, 9, 531-542.

41. Bui, N.A.; Kiatkawsin, K. Examining Vietnamese Hard-Adventure Tourists' Visit Intention Using an Extended Model of GoalDirected Behavior. Sustainability 2020, 12, 1747. [CrossRef]

42. Minotta, D.G. El turismo joven: Conceptualización y alcances. Rev. Intersección Even. Tur. Gastron. Moda 2014, 2, $43-54$.

43. Franco, W.C.; Franco, M.C.; Franco, O.C.; Lino, X.R. Preferencias para el turismo de aventura en la elaboración de un paquete turístico: Caso Santa Elena, Ecuador. Rev. Interam. Ambiente Tur. 2018, 14, 43-51. [CrossRef]

44. Mogollón, J.M.H.; Cerro, A.M.C.; di Clemente, E. El turista rural en entornos de alta calidad medioambiental. Rev. Análisis Turístico 2013, 16, 21-31.

45. Leco, F.; Pérez, A.; Hernández, J.; Campón, A. Rural tourists and their attitudes and motivations towards the practice of environmental activities such as agrotourism. IJER 2013, 17, 255-264.

46. Henche, B.G. Características diferenciales del producto turismo rural. Cuad. Tur. 2005, 15, 113-134.

47. Giddy, J.K.; Webb, N.L. The influence of the environment on adventure tourism: From motivations to experiences. Curr. Issues Tour. 2018, 21, 2124-2138. [CrossRef] 
48. Muñoz, E.E.; Milla, M.C.; Tiznado, J.L. Turismo de aventura, su impacto ambiental y propuesta de mitigación en la quebrada de Quillcayhuanca. Rev. Investig. Univ. Le Cordon Bleu 2017, 4, 59-70.

49. Tinoco, O. Los impactos del turismo en el Perú. Ind. Data 2003, 6, 47-60. [CrossRef]

50. Blanco, R.; Benayas, J. Los Estudios de Capacidad de Acogida y su Contribución Para Establecer Modelos de Turismo Sostenible en Espacios Naturales; Departamento de Ecología. Universidad Autónoma de Madrid: Madrid, Spain, 1998.

51. Tello, S. Patrimonio: Turismo y comunidad. Rev. Tur. Patrim. 2000, 1, 151-163. [CrossRef]

52. Nicolau, J.L. Determinantes de la Motivación Cultural en la Elección de Destinatarios; El Caso Español: Madrid, Spain, 2009.

53. Gobierno, D.E. Plan de Acción para la Implementación de la Agenda 2030. Hacia una Estrategia Española de Desarrollo Sostenible. 2018. Available online: http://www.exteriores.gob.es/Portal/es/SalaDePrensa/Multimedia/Publicaciones/ Documents/PLAN\%20DE\%20ACCION\%20PARA\%20LA\%20IMPLEMENTACION\%20DE\%20LA\%20AGENDA (accessed on 16 December 2020).

54. Márquez, L.A.M.; Colmenares, S.P. Revisión sobre capacidad de carga turística y la prevención de problemas ambientales en destinos emergentes. Anu. Tur. Soc. 2019, 24, 77-100. [CrossRef]

55. Sati, V.P. Carrying capacity analysis and destination development: A case study of Gangotri tourists/pilgrims' circuit in the Himalaya. Asia Pac. J. Tour. Res. 2018, 23, 312-322. [CrossRef]

56. Mateos, A.B.; Leco, F.; Pérez, A. Visitors' Perception of the Overcrowding of a Protected Natural Area: A Case Applied to the Natural Reserve "Garganta de los Infiernos"(Caceres, Spain). Sustainability 2020, 12, 9503. [CrossRef] 